DOI: $10.20472 /$ IAC.2018.035.014

\author{
HANA FLORIANOVÁ \\ Masaryk University, Czech Republic
}

KAREL URBANOVSKÝ

Masaryk University, Czech Republic

\title{
PRIMARY CHARACTERISTICS OF AN AVERAGE CZECH INVESTOR
}

\begin{abstract}
:
The aim of this paper is to find the basic characteristics of an average Czech investor - consumer in a capital market. According to the Directive 2005/29/EC of the European Parliament and of the Council the average consumer is a person who is reasonably well-informed and reasonably observant and circumspect, taking into account social, cultural and linguistic factors, as interpreted by the Court of Justice, but also contains provisions aimed at preventing the exploitation of consumers whose characteristics make them particularly vulnerable to unfair commercial practices. This definition is based on indefinite terms which national law usually does not specify. At the same time, there is a need for understanding, who exactly the average consumer (investor) is, especially when judging disputes on investment or other matters on capital markets. The aim of our research is therefore to find the answer for the question "Who is the average consumer on a capital market?"
\end{abstract}

\section{Keywords:}

capital market, average consumer, investments, investing, investor

JEL Classification: G11, G23 